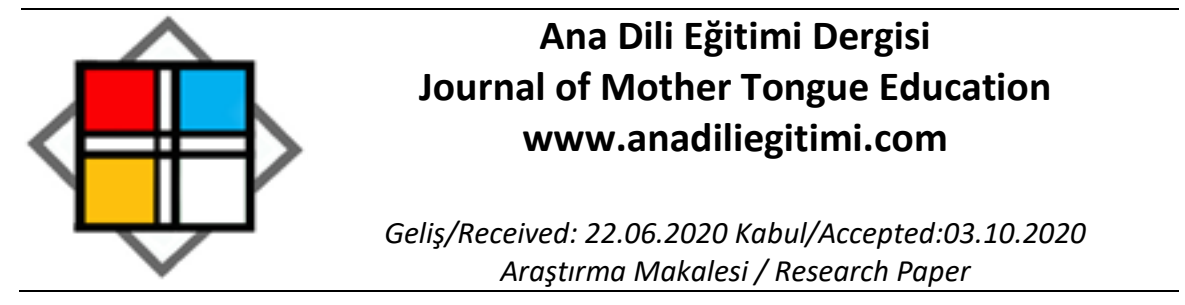

\title{
Sınıf Öğretmeni Adaylarının İlkokuma Yazma Öğretiminde Animasyon ve Simülasyon Kullanımına Yönelik Deneyimleri ile ilgili Görüşleri ${ }^{* * *}$
}

\begin{abstract}
Serkan $A S L A N^{* * *}$
Öz

$\mathrm{Bu}$ araştırmanın amacı, sınıf öğretmeni adaylarının ilkokuma yazma öğretiminde animasyon ve simülasyon kullanımı ile ilgili deneyimlerine yönelik görüşlerini incelemektir. Araştırmada nitel araştırma modeli kullanılmıştır. Araştırmanın katılımcılarını sınıf eğitimi ana bilim dalında, dördüncü sınıfta öğrenim görmekte olan 24 öğretmen adayı oluşturmaktadır. Araştırmada veri toplama aracı olarak açık uçlu sorulardan oluşan bir anket formu kullanılmıştır. Verilerin analizinde nitel veri analizlerinden biri olan içerik analizi kullanılmıştır. Araştırmada öğretmen adaylarının ilkokuma yazma öğretiminde animasyon ve simülasyon kullanımına olumlu baktıkları, ilkokuma yazma öğretiminde animasyon ve simülasyon kullanımının öğrencilerin akademik başarıların arttırdığı, kalıcı öğrenmelerini sağladığını, motivasyonlarını arttırdığı, harfleri öğrenmelerini kolaylaştırdığı, öğretmenlerin bilgisayar kullanma ve dijital teknolojiyi kullanma becerilerini geliştirdiği, dersin etkili, verimli ve eğlenceli geçmesine katkı sağladığı, zamanın tasarruflu kullanıldı̆̆ı, disiplin problemlerini azalttığı, derinlemesine öğrenmeyi sağladığı sonuçları elde edilmiştir. Araştırma sonucunda öğretmen adayları ses esaslı ilkokuma yazma öğretiminin daha çok sesi hissetme ve tanıma aşamasında animasyon ve simülasyon kullandıklarını belirtmişlerdir. Öğretmen adayları, ilkokuma ve yazma öğretiminde animasyon ve simülasyon kullanımında zamanın yetersiz olması, animasyon ve simülasyon hazırlanmasında güçlüklerin olması gibi sorunlarla karşılaştıklarını belirtmişlerdir.
\end{abstract}

Anahtar Kelimeler: Teknoloji entegrasyonu, animasyon, simülasyon, ilkokuma yazma öğretimi

\section{Elementary Prospective Teachers Views on the Use of Animation and Simulation in First Reading and Writing Teaching}

\begin{abstract}
The aim of this study is to examine the views of elementary prospective teachers about their experiences with the use of animation and simulation in first reading and writing teaching. Qualitative research model was used in the research. The participants of the study consisted of 24 prospective teachers studying in the department of classroom education. In the research, a questionnaire consisting of open-ended questions was used as a data collection tool. Content analysis, one of the qualitative data analyzes, was used in the analysis of the data. In the study, teacher prospective positively viewed the use of animation and simulation in teaching first reading and writing, the use of animation and simulation in teaching first reading and writing increased students 'academic achievement, provided permanent learning, increased motivation, facilitated their learning of letters, improved teachers' ability to use computers and digital technology, and the course was effective and efficient, and it contributes to having fun, it saves time, reduces
\end{abstract}

\footnotetext{
* Araştırmanın etik kurulu izni: Süleyman Demirel Üniversitesi Sosyal ve Beşeri Bilimler Etik Kurulu, 05.03.2020, 874329561/050.991/89.9

** Bu makalenin bir bölümü Uluslararası Pegem Eğitim Kongresi'nde (16-19/09/2020) sözlü bildiri olarak sunulmuştur.

*** Dr. Öğr. Üyesi, Süleyman Demirel Üniversitesi, Eğitim Fakültesi, Eğitim Bilimleri Bölümü, Isparta, serkanaslan@sdu.edu.tr, ORCID: 0000-0001-8515-4233.
} 
discipline problems, and provides in-depth learning. As a result of the research, prospective teachers stated that they used animation and simulation in the phase of feeling and recognizing more sound based teaching. Preservice teachers stated that they encountered problems such as insufficient time in the use of animation and simulation in first reading and writing teaching, and difficulties in preparing animation and simulation. Suggestions have been developed for the problems faced by prospective teachers, which will attract the students' attention, simulation programs should be learned well, animation and simulations appropriate for student level should be prepared and used.

Keywords: Technology integration, animation, simulation, first reading and writing teaching

\section{Giriş}

Yirmi birinci yüzyılda bilim ve teknolojide önemli gelişmeler yaşanmıştır. Bu gelişmeler hayatın her alanını etkilediği gibi eğitim alanını da etkilemiştir. Özellikle son yıllarda eğitim alanında teknoloji entegrasyonuna yönelik çalışmalar yapılmaya başlanmış ve öğretim programlarında teknoloji entegrasyonuna yönelik değişiklikler gerçekleştirilmiştir. Türkiye'de de son yıllarda eğitim alanında teknoloji entegrasyonuna yönelik birçok çalışma yapılmaya başlanmıştır. 2018 yılında güncellenen öğretim programları incelendiğinde teknoloji entegrasyonuna yönelik değişikliklerin olduğu göze çarpmaktadır. Eğitimde teknoloji entegrasyonu her derste yapılmalıdır. Özellikle ilkokuma yazma öğretiminde teknoloji entegrasyonunun sağlanması öğrencilerin okuma yazmaya başlamasına katkı sağlayacaktır. Yıldız (2009) tarafından yapılan tez çalışmasında ilkokuma yazma öğretiminde çoklu ortamların öğrencilerin okuma yazma becerilerini geliştirdiği sonucu elde edilmiştir. Bu sonuç, teknoloji entegrasyonun okuma ve yazma becerilerinin kazandırımasında etkili olduğunu ortaya koymaktadır.

Okuma ve yazma becerilerinin kazanılması bireyin hayatında önemli bir yere sahiptir. Okuma yazma süreci insanlığın geçmişi ile bağ kurmasının yanı sıra insanlığın tecrübelerini yeni nesillere iletmeyi sağlar, aynı zamanda nesiller arasında da iletişim sağlayarak, önemli bir vazife üstlenir (Birgül, 2014:2). Bu bakımdan okuma yazma öğretim sürecinde öğretmenlere önemli sorumluluklar düşmektedir. Nitelikli bir okuma yazma öğretim süreci gerçekleştirebilmek için öğretmenlerin bu süreçte teknoloji entegrasyonu sağlaması son derece önem arz eden bir konu hâline gelmiştir. Günüç (2017) eğitimde teknoloji entegrasyonunun öğrencilerin akademik başarılarını arttırdığını, bireysel gelişimini sağladığını, öğrenmeye yönelik motivasyonunu arttırdığını, eğlenerek öğrenmeyi, etkili ve kalıcı öğrenmeyi sağladığını belirtmiştir. Bu nedenle, ilkokuma yazma öğretiminde teknoloji entegrasyonunun sağlanması durumunda, daha eğitim hayatlarının ilk yıllarında öğrencilerin okula, öğretmene ve derse yönelik tutumları olumlu yönde gelişebilir. Bu dönemde yaşanan okul korkusu teknoloji entegrasyonu sayesinde en aza indirilebilir. Ayrıca öğrencilerin kısa sürede okur yazar olmalarına katkı sağlayabilir.

Öğretmenlerin öğretim programlarına dayalı teknoloji entegrasyonu sağlaması oldukça güçtür. Nitekim Günüç (2017) eğitimde teknoloji entegrasyonunda öğretmenlerin teknoloji kullanımına ön yargılı olması, teknolojiyi kullanamama, teknolojik araç-gereçleri gereksiz bulması gibi engellerin olduğunu belirtmiştir. Bu nedenle öğretmenlere teknoloji entegrasyonuna yönelik deneyim kazandırmak gerekmektedir. Bunun için öğretmenlere hizmet öncesi eğitimlerinde, animasyon ve simülasyon gibi araçların kullanımına yönelik deneyim kazandırmak son derece yararlı olacaktır.

Animasyon, görüntülerin belli bir sırada, düzende ve hızda gösterilmesiyle hareket ediyormuş izlenimini veren bir bilgisayar yazılımıdır (Funge, 1998; Chong, Sourin \& Levinski, 2006). Eğitimde animasyon kullanımının birçok faydası bulunmaktadır. Animasyonlar konuların aktarılmasında, öğrencilere somut yaşantılar sağlayarak, öğrencilerin yaratıcı düşünceler geliştirmelerine olanak vermektedir. Dolayısıyla öğrenme serüveni daha etkin halde gerçekleşmektedir. Bu durum öğrencilere bireysel öğrenme ortamları da sunmaktadır (Arıcı \& Dalkılıç, 2006). Animasyonun kullanımı eğitim bilimlerinde uygulamalı bir strateji olarak öğrencilerin konuları tekrar etmelerine yardımcı olmakta ve öğrenilen bilgilerin kalıcılığına olumlu yönde katkı sağlamaktadır (Karaçöp, 2010). Animasyon programları ile:

$>\quad$ Tehlikelilik durumunun ortadan kalkması,

$>\quad$ Her türlü araç ve gerecin kontrollünün sağlandığı ortam olması,

$>\quad$ Maliyeti azaltması, 
> Yapılması güç olan deneyler için istenilen deneyin defalarca yapılması yerine animasyon programları ile aktarılması öğretim ortamına fayda sağlamaktadır (Beşkirli, 2011).

Animasyonlarla birlikte simülasyon kullanımı da eğitim alanında yaygınlaşmaya başlamıştır. Simülasyonlar, fiziksel ve sosyal etkileşimin bulunduğu basitleştirilmiş gerçeklik sunan öğrenme araçlarıdır (Zapalska, Brozik \& Rudd, 2012: 165). Simülasyon oyunları birçok farklı disiplinde kullanılabilir ve uyarlanabilir (Klassen \& Willoughby, 2003). Shubik (2009) ise simülasyon birçok faydasından bahsetmiştir. Bunlar:

1. Öğrenme motivasyonunu artırma,

2. Eğitimdeki diğer metotların kullanımını güçlendirme,

3. Neden, nasıl, ilişkisi ile birlikte teorileri öğretme,

4. Dinamik durumları öğretmede anlam kurma,

5. Kişilerarası ilişkileri geliştirme ve öğretme,

6. Çocukların kültürleme sürecine katkı sağlama,

7. Çeşitli beceriler kazandırma (akademik beceriler, yaşamsal beceriler vb.).

Sarıçayır (2007) simülasyonların güvenilir olması, sonsuz deneme imkânı tanıması, ucuz olması, problem çözme, keşfetme ve eleştirel düşünme becerilerini geliştirmesi, soyut kavramları somutlaştırması gibi avantajlarının olduğunu belirtmiştir. Görüldüğü üzere animasyon ve simülasyonların eğitim ortamında birçok faydası bulunmaktadır. Bu bakımdan ilkokuma yazma öğretiminde de animasyon ve simülasyon kullanımının öğrencilere birçok katkısının olacağını söylemek hiç de abartılı olmayacaktır.

Türkiye'de 2005-2006 eğitim öğretim yılından öğretim programlarında yapılandırmacı öğrenme yaklaşımı temele alınarak değişiklikler yapılmıştır. Bu değişikliklerle birlikte ilkokuma yazma öğretiminde de cümle yöntemi terk edilerek ses temelli cümle yöntemi ilkokuma yazma öğretiminde kullanılmaya başlanmıştır. Son olarak, 2018 yılında güncellenen öğretim programları ile birlikte ses esaslı okuma-yazma yöntemiyle öğrencilere okuma ve yazma öğretilmeye başlanmıştır. Ses esaslı ilkokuma yazma öğretiminin aşamaları şu şekildedir (Millî Eğitim Bakanlığı [MEB], 2019):

1) ilk okuma yazmaya hazırlık

a) Dinleme eğitimi çalışmaları

b) Parmak, el ve kol kaslarını geliştirme çalışmaları

c) Boyama ve çizgi çalışmaları

2) ilk okuma yazmaya başlama ve ilerleme

a) Sesi hissetme, tanıma ve ayırt etme

b) Harfi okuma ve yazma

c) Harflerden heceler, hecelerden kelimeler, kelimelerden cümleler oluşturma

d) Metin okuma

3) Bağımsız okuma ve yazma.

Ses esası ilkokuma yazma öğretiminin tüm aşamalarına yönelik teknoloji entegrasyonu yapılabilir. Bu aşamlarda animasyon ve simülasyonlar kullanılabilir. Bu şekilde öğrencilere okuma ve yazma becerileri kazandıralabilinir. Nitekim Aladağ (2012) tarafından yapılan araştırma neticesinde öğretmenler tarafından böyle bir görüş belirtilmiştir.

İlkokul birinci sınıf öğrencilerinin hayatını etkileyecek en önemli beceriler olan okuma ve yazmanın nitelikli bir şekilde öğrencilere kazandırıması son derece önem arz eden bir konudur. Bu nedenle, ilkokuma yazma öğretiminde teknoloji entegrasyonun yapılması gerekmektedir. Teknoloji entegrasyonuna dayalı olarak yapılan eğitimin öğrencilere birçok katkısının olduğu yukarıda bahsedilmiştir. Bu bakımdan öğretmenlerin teknoloji entegrasyonu ile ilgili bilgilerinin olması ve son gelişen teknolojiyi öğretme ortamında kullanmaları gerekmektedir. Bunlardan ikisi de animasyon ve simülasyon uygulamalarıdır. Yukarıda da belirtildiği üzere animasyon ve simülasyon uygulamalarının öğrencilere birçok katkısı bulunmaktadır. Öğretmenlerin ilkokuma yazma öğretiminde animasyon kullanabilmeleri için bu konu ile ilgili hizmet öncesi eğitimlerinde bilgilerinin ve deneyimlerinin olması gerekmektedir. Bu araştırmada, araştırmacı tarafından katılımcılara 3. Sınıfta, 2018-2019 eğitim öğretim yılının güz döneminde ilkokuma ve yazma dersi verilmiştir. Araştırmacı tarafından bu derste öğretmen adaylarına tüm harfler ile ilgili animasyonlar ve simülasyonlar geliştirilmiştir. Bu sayede 
öğretmen adaylarının seslerin öğretimi noktasında animasyon ve simülasyon kullanımına yönelik deneyim kazanmaları sağlanmıştır. Sınıf öğretmenliğinde öğrenim gören öğretmen adayları güz ve bahar dönemlerinde öğretmenlik uygulaması çerçevesinde staj yapmaktadırlar. Öğretmen adayları, 4. sınıfta, 2019-2020 eğitim öğretim yılının güz döneminde yaptıkları stajlarda özellikle ilkokul birinci sınıflara okuma ve yazma öğretimi yaptıklarını, okuma yazma öğretiminde animasyon ve simülasyon kullandıklarını araştırmacıya söylemişlerdir. Ayrıca öğretmen adayları, bu şekilde okuma yazma öğretiminin öğrencilere birçok katkısının olduğunu belirtmişlerdir. Yaşanan bu durum üzerine böyle bir çalışmanın yapılmasının anlamlı olacağı ve Türkiye'deki alanyazına katkı sağlayacağı düşünülmüştür. Araştırmanın çıkış noktası bu şekilde olmuştur. Araştırmacı tarafından, güz döneminin sonuna doğru, veri toplama aracı öğretmen adaylarına dağıtılarak görüşleri alınmıştır. Öğretmen adaylarının deneyimlerinden yola çıkarak ilkokuma yazma öğretiminde animasyon ve simülasyon kullanımına yönelik deneyimlerinin incelenmesi araştırmaya değer bir konu olarak görülmüştür. Alanyazında bu konu ile ilgili herhangi bir çalışmaya rastlanılmaması bir eksiklik olarak görülmüş ve bu çalışmanın alanyazındaki bu boşluğu dolduracağı düşünülmüştür.

Bu araştırmanın amacı, sınıf öğretmeni adaylarının ilkokuma yazma öğretiminde animasyon ve simülasyon kullanımına ilişkin deneyimleri ile ilgili görüşlerini incelemektir. Bu kapsamda aşağıdaki sorulara yanıt aranacaktır:

1. Öğretmen adaylarının animasyon ve simülasyon kullanımı ile ilgili görüşleri nelerdir?

2. Öğretmen adaylarının ilkokuma yazma öğretiminde animasyon ve simülasyon kullanımının katkısına yönelik görüşleri nelerdir?

3. Öğretmen adaylarının ses esaslı ilkokuma yazma öğretim sürecinin hangi aşamasında animasyon ve simülasyon kullandıklarına ve neden bu aşamada animasyon ve simülasyonları seçtiklerine yönelik görüşleri nelerdir?

4. Öğretmen adaylarının ilkokuma yazma öğretiminde animasyon ve simülasyon kullanımı ile ilgili yaşamış oldukları sorunlar nelerdir?

5. Öğretmen adayları ilkokuma yazma öğretiminde animasyon ve simülasyon kullanımı ile ilgili karşılaşmış oldukları sorunlara yönelik hangi çözüm önerilerini geliştirmişlerdir?

\section{Araştırmanın Modeli}

\section{Yöntem}

Araştırmada nitel araştırma modeli kullanılmıştır. Nitel araştırma "sosyal fenomenleri, insan davranışlarını ve bu davranışların sebeplerinin neler olduğunu detaylı ve derin bir şekilde anlamayı amaçlayan bir araştırma yöntemidir. Bu yöntem içerisinde insanların algılamalarının, deneyimlerinin ve tutumlarının derin bir şekilde incelenmesi yatmaktadır." (Güler, Halıcıoğlu \& Taşğın, 2014: 39). Nitel araştırma kapsamında, görüşme, gözlem, anket, resimler, fotoğraflar, çeşitli belgeler gibi veri toplama araçları kullanılabilmektedir (Güçlü, 2019; Sığrı, 2019; Yıldırım \& Şimşek, 2018). Bu araştırmada da sınıf öğretmeni adaylarının deneyimlerinden faydalanarak ilkokuma yazma öğretiminde animasyon ve simülasyon kullanımı ile ilgili görüşleri incelendiğinden nitel araştırma modeli kullanılmıştır.

\section{Katılımcılar}

Araştırmanın katılımcılarını Süleyman Demirel Üniversitesi, sınıf öğretmenliği ana bilim dalında, dördüncü sınıflarda öğrenim gören öğretmen adayları oluşturmaktadır. Araştırmanın katıımcıları belirlenirken ölçüt örnekleme yöntemi kullanılmıştır. Ölçüt örnekleme, önceden belirlenmiş bazı önemli ölçütleri karşılayan katılımcıların seçilmesi oluşturulan örnekleme yöntemidir (Patton, 2005). Bu araştırma kapsamında da katılımcıların, animasyon ve simülasyon geliştirip bunları ilkokuma yazma öğretiminde kullanmış olmaları ölçütü belirlenmiştir. Bu ölçütün belirlenmesinin temel nedeni, katılımcılardan ilkokuma yazma öğretiminde animasyon ve simülasyon kullanımına yönelik sağlıklı bilgilerin alınacağı düşüncesidir. Bu ölçüt sayesinde, araştırmanın amacına dayalı olarak öğretmen adaylarının deneyimlerine yönelik görüşleri incelenmiştir. Araştırmanın katılımcılarııın 13'ünü kadın, 11'ini erkek öğretmen adayı oluşturmaktadır. 


\section{Veri Toplama Aracı}

Araştırmada veri toplama aracı olarak anket formu kullanılmıştır. Anket, katılımcıların bir konuda düşünce, tutum ve davranışlarını daha önce belirlenmiş bir sırada ve yapıda oluşturulmuş sorulara dayalı olarak elde etmeyi sağlamaktadır. Ankette açık uçlu sorular da sorulabilmektedir (Gürbüz \& Şahin, 2018:175-176). Bu araştırmada da, sınıf öğretmeni adaylarının ilkokuma yazma öğretiminde animasyon ve simülasyon kullanımına yönelik deneyimleri ile ilgili görüşlerini incelemek amacıyla geliştirilen anket formu kullanılmıştır. Anket formundaki sorular açık uçlu sorulardan oluşmaktadır. Form geliştirilirken alanyazın incelenmiş ve bunun neticesinde açık uçlu sorular hazırlanmıştır. Daha sonra hazırlanan anket formu animasyon ve simülasyon ile ilkokuma ve yazma öğretimi ile ilgili çalışma yapan üç alan uzmanına sunulmuştur. Alan uzmanlarından gelen görüşler neticesinde anket formu düzenlenmiştir. Anket formunun pilot uygulaması yapılarak beş sınıf öğretmeni adayına geliştirilen anket formu uygulanmıştır. Öğretmen adaylarına anket formunun uygulanması esnasında herhangi bir sorunla karşılaşılmaması üzerine asıl uygulamaya geçilmiş ve anket formu katılımcılara uygulanmıştır.

\section{Verilerin Toplanması}

Araştırmacı tarafından hazırlanan anket formu, 9-13/12/2019 tarihleri arasında araştırmaya gönüllü olarak katılan öğretmen adaylarına uygulanmıştır. Öğretmen adaylarının eğitim-öğretimlerini aksatmayacak şekilde boş zamanlarında anket formları doldurulmuştur. Öğretmen adayları ortalama 35 dakikada anket formundaki açık uçlu soruları cevaplamışlardır.

\section{Verilerin Analizi}

Verilerin analizinde nitel veri analizlerinden biri olan içerik analizi kullanılmıştır. İçerik analizi, mesaj değeri taşıyan her türlü verinin bir amaç doğrultusunda taranması, temalara ayrılması, özetlenmesi ve bulguların araştırma amacı doğrultusunda analiz edilmesini ve yorumlanmasını içermektedir (Karagöz, 2017:602). Sönmez ve Alacapınar (2018) içerik analizinde, metnin, belgenin içeriğinin irdelenmesi gerektiğini, elde edilen verilerin birbirleriyle ilişkilendirilip temalara ayrılması gerektiğini söylemişlerdir. Bu araştırmada da, öğretmen adaylarının anket formuna vermiş oldukları cevaplar tek tek incelenerek önce kodlara ulaşılmış, daha sonra bu kodlar birbirleriyle ilişkilendirilerek temalar oluşturulmuştur. Veriler Nvivo 11 programı kullanılarak analiz edilmiş ve elde edilen bulgular şekillerle sunulmuştur.

\section{Araştırmada Geçerlik ve Güvenirlik}

Nitel araştırmalarda geçerliği ve güvenirliği sağlamak için çeşitli stratejiler kullanılmaktadır. Nitel araştırmalarda geçerlik ve güvenirliği sağlamada uzman görüşü alma, katılımcı teyidi, kodlamalar arasında uyuşma, doğrudan alıntılama yapma gibi çeşitli stratejiler işe koşulabilmektedir (Creswell, 2007; Güler, Halıcıoğlu \& Taşğın, 2014; Yalçın, 2017). Bu araştırmada da, geçerliği ve güvenirliği sağlamak için yapılan kodlamalar ve temalar iki alan uzmanına sunulmuş ve aralarındaki uyuşmaya bakılmıştır. Uyuşma olmadığı durumlarda ise uzlaşılmaya çalışılmış ve nihayi sonuç elde edilmiştir. Ayrıca araştırmaya katılan 7 öğretmen adayına elde edilen kodlar ve temalar sunularak görüşleri alınmıştır. Katılımcılar kodlamaların ve temaların uygun olduğunu belirmişlerdir. Araştırma kapsamında katıımcılardan doğrudan alıntılamalar yapılarak da geçerlik ve güvenirlik sağlanılmaya çalışılıı̧tır.

\section{Araştırmada Alınan Etik Önlemler}

Nitel araştırmalarda, katılımcıların rızalarının alınması, araştırma kapsamında herhangi bir şekilde zarar görmeyecekleri, isimlerinin gizli tutulacağı ve araştırma bulgularının araştırma kapsamı dışında kullanılmayacağı gibi etik ilkelere uyulması gerektiği belirtilmektedir (Güçlü, 2019; Güler, Halıııoğlu \& Taşğın, 2014; Hammersley \& Traianou, 2012). Araştırma kapsamında etik ilkelere dikkat edilmiştir. Katılımcıların rızaları alınarak araştırmaya katılımları sağlanmıştır. Anket formu uygulanmadan önce bilgilendirme yapılmış ve izinleri alınmıştır. Araştırma kapsamında herhangi bir şekilde zarar görmeyecekleri belirtilmiş ve anket formuna kesinlikle isimlerini yazmamaları gerektiği söylenmiştir. Katılımcıları isimlerine araştırmada yer verilmemiştir. Araştırma kapsamında öğretmen 
adaylarına ait doğrudan alıntılarda anonimlik ilkesine dikkat edilmiş ve ÖA:1, K (Öğretmen Adayı:1, Kadın) gibi kodlar kullanılmıştır. Araştırma verilerinin araştırma kapsamı dışında kullanıımayacağı ve verilerin gizli tutulacağı belirtilmiştir. Araştırmanın tüm aşamalarında etik ilkelere riayet edilmiştir.

\section{Etik Kurulu İzni}

Araştırma verileri toplanırken katılımcı onam formları öğrencilere dağıtılıp imzalanmıştır. Araştırma kapsamında etik kurul kararı alınmıştır.

Kurul adı = Süleyman Demirel Üniversitesi Sosyal ve Beşeri Bilimler Etik Kurulu

Karar tarihi $=05.03 .2020$

Belge sayı numarası $=874329561 / 050.991 / 89.9$

\section{Bulgular}

$\mathrm{Bu}$ başlık altında araştırmanın alt problemlerine dayalı olarak bulgular sunulmuştur. Araştırmanın birinci alt problemine dayalı olarak, sınıf öğretmeni adaylarının animasyon ve simülasyon ile ilgili görüşleri alınmış ve elde edilen bulgular Şekil 1'de sunulmuştur.

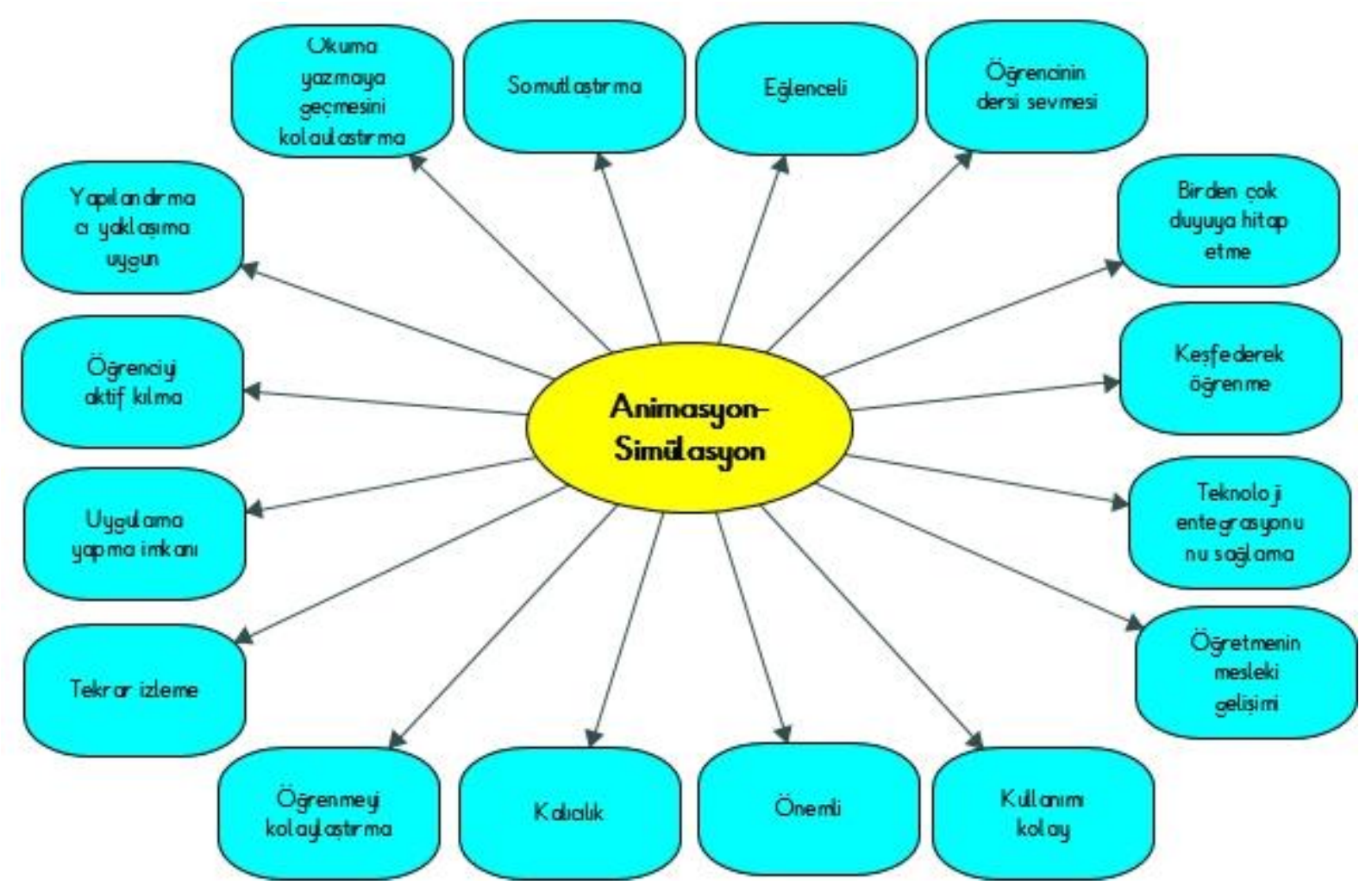

Şekil 1. Öğretmen Adaylarının Animasyon ve Simülasyon ile İlgili Görüşleri

Şekil 1 incelendiğinde öğretmen adayları, animasyon ve simülasyon ile ilgili olarak olumlu görüşlere sahip olduğu görülmektedir. Öğretmen adayları animasyon ve simülasyon ile ilgili olarak kullanımlarının kolay olduğunu, ilkokuma yazma öğretiminde kullanılmasının önemli olduğunu, öğrenmeyi kolaylaştırdığını, kalıcı öğrenmeyi sağladığını, öğrencilerin okuma yazmaya geçmesini kolaylaştırdığını, somutlaştırmayı sağladığını, eğlenceli olduğunu, öğrencilerin dersi sevmelerini sağladığını, birden çok duyuya hitap ettiğini, keşfederek öğrenmeyi sağladığını, öğretme-öğrenme sürecine teknoloji entegrasyonunu sağladığını, öğretmenin mesleki gelişimine katkı sağladığını, yapılandırmacı yaklaşıma uygun olduğunu, öğrenciyi öğretme-öğrenme sürecinde aktif kıldığını, öğrencilere uygulama yapma imkanı verdiğini ve öğrencilerin tekrar izlemesini sağladığını belirtmişlerdir. Bazı öğretmen adaylarına ait görüşlere aşağıda yer verilmiştir.

"Animasyon ve simülasyon kullanımının ilkokuma ve yazma öğretiminde çok önemli olduğunu düşünüyorum. Animasyon ve simülasyon kullanarak öğrencilerimizin daha erken okur yazar olacağını 
Sınıf Öğretmeni Adaylarının İlkokuma Yazma Öğretiminde Animasyon ve Simülasyon Kullanımına Yönelik Deneyimleri ile İlgili Görüşleri

düşünüyorum. Kullanımı da kolaydır. Öğrencilerin öğrendiklerini kalıcı hale getirmektedirler. Yani öğrencilerin öğrendikleri konuları unutmazlar ve hep hatırlarlar." (ÖA:1 K)

"Animasyon ve simülasyon sayesinde öğrenme kolaylaşmaktadır. Bu sebeple ilkokuma yazma öğretiminde animasyon ve simülasyon kullanımı ögrencilerin sesleri tanımasında, sesleri ayırt etmesinde, heceler oluşturmasında, hecelerden kelimeler oluşturmasında, kelimelerden cümleler oluşturmasını görsellerle, interaktif oyunlarla desteklemektedir. Bu şekilde öğrencilerin harfleri okuyup yazmaları kolaylaşırken öğrenciler soyut olan yazıyı somutlaştırarak öğrenmektedir." (ÖA:2, K)

Araştırmanın ikinci alt problemine dayalı olarak, sınıf öğretmeni adaylarının animasyon ve simülasyonun ilkokuma yazma öğretiminde kullanımına yönelik katkısı ile ilgili görüşleri alınmış ve elde edilen bulgular Şekil 2'de sunulmuştur.

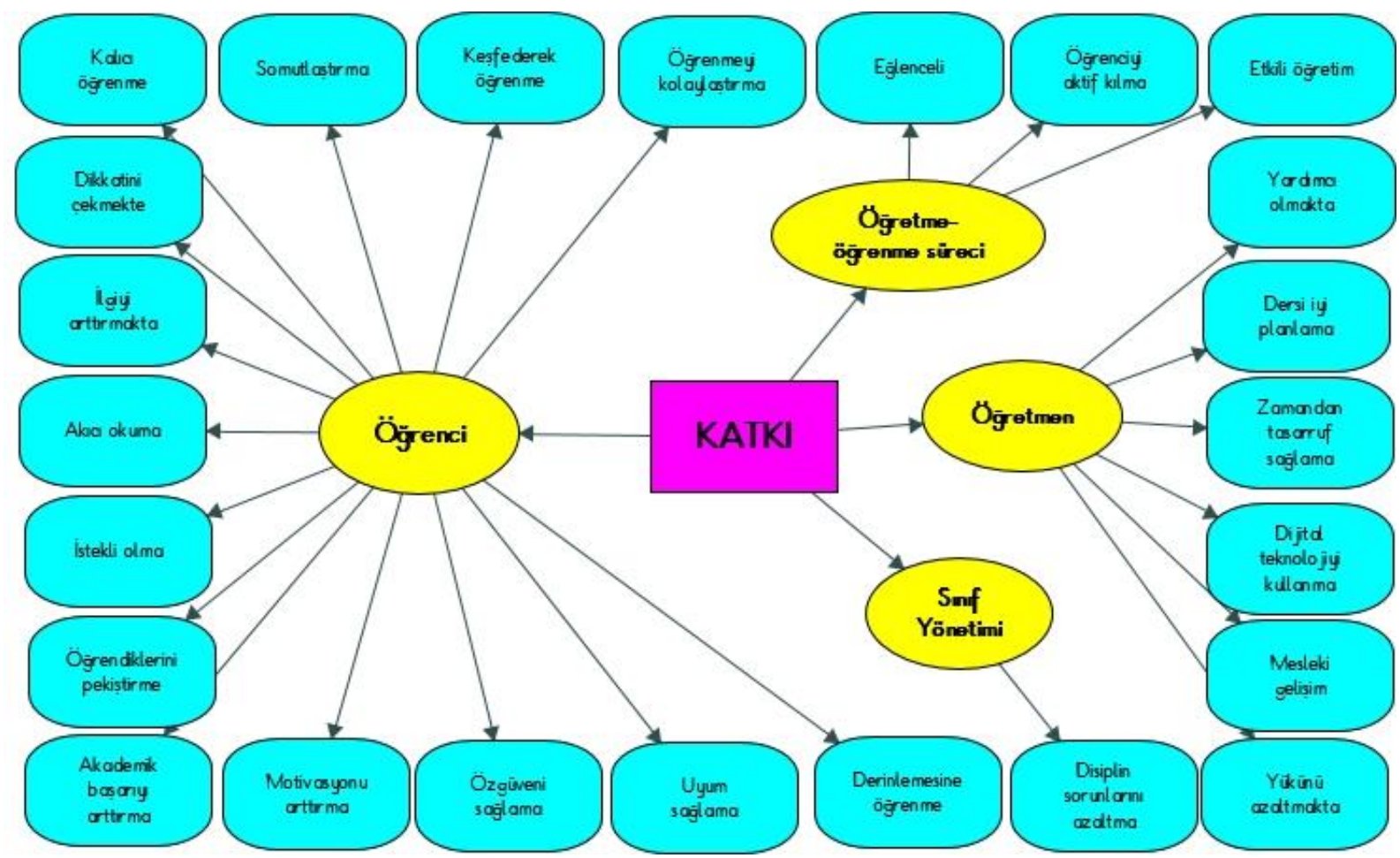

Şekil 2. Öğretmen Adaylarının Animasyon ve Simülasyon İlkokuma Yazma Öğretiminde Kullanımına Yönelik Katkısı İle Illgili Görüşleri

Şekil 2 incelendiğinde öğretmen adayları, ilkokuma yazma öğretiminde animasyon ve simülasyon kullanımının öğrenciye, öğretmene, öğretme-öğrenme sürecine ve sınıf yönetimine katkı sağladığını belirtmişlerdir. Öğretmen adayları tarafından, öğretme-öğrenme ortamında animasyon ve simülasyon kullanımının en çok öğrenciye katkı sağladığı belirtilmiştir. Öğretmen adayları öğrenci temasında, kalıcı öğrenmeyi sağladığını, somutlaştırmayı sağladığını, öğrenmeyi kolaylaştırdığını, öğrencilerin dikkatini çektiğini, ilgisini arttırdığını, akıcı okumalarını sağladığını, istekli olmalarını sağladığını, öğrendiklerini pekiştirmelerine yardımcı olduğunu, akademik başarılarını ve motivasyonunu arttırdığını, özgüvenlerini sağladığını, derse uyum sağlamalarına yardımcı olduğunu, derinlemesine öğrenmelerini sağladığını belirtmişlerdir. Öğretmen adayları öğretme-öğrenme süreci temasında, öğrenme-öğretme sürecinin eğlenceli olmasını sağladığını, bu süreçte öğrenciyi aktif kıldığını, etkili öğretimin gerçekleşmesine yardımcı olduğunu belirtmişlerdir. Bir öğretmen adayının görüşü şu şekildedir:

"Öğrencilerin okumalarının akıcı olmasını sağlar. Öğrenciler sesleri, kelimeleri daha iyi tanıyorlar ve bu sayede akıcı okumaları da gelişecektir. Animasyon simülasyon öğrencinin ilgisini de çekmektedir. Sınıf yönetimine de katkı sağlamaktadır. Disiplin problemleri yaşanmamaktadır. Öğrencilerin derse daha kolay adapte olmalarını sağladığını gördüm." (ÖA:24, E) 
Öğretmen adayları öğretmen teması altında, öğretmenlere harflerin öğretilmesinde yardımcı olduğunu, öğretmenlerin dersi iyi planlamalarına katkı sağladığını, zamandan tasarruf sağladıklarını, dijital teknolojiyi kullanma becerilerini geliştirdiğini, mesleki gelişimlerine katkı sağladıklarını, yükünü azalttıklarını; sınıf yönetimi temasında disiplin sorunlarını azalttığını belirtmişlerdir. Öğretmen adayı 16'nın görüşü şu şekildedir:

"ilkokuma yazma ögrretiminde animasyon ve simülasyon kullanımı öğretmenin zamandan tasarruf etmesine katkı sağlar. Öğretmen tek tek her öğrenciye harfleri, kelimeleri yazdırmaya veya okutmaya çalışmaktansa aynı anda animasyon ve simülasyon sayesinde bunu yapabilir. Bu da zamandan tasarruf sağlamlarına neden olur. Animasyon ve simülasyon öğrencilerin derse dikkatlerini çekmelerine de katkı sağlıyor. Dersle daha ilgili oluyorlar. Gittiğimiz okullarda animasyon ve simülasyon kullandığımızda bunu daha iyi gördüm." (ÖA:16, K)

Araştırmanın üçüncü alt problemine dayalı olarak, sınıf öğretmeni adaylarııın ses esaslı ilkokuma yazma öğretim sürecinin hangi aşamasında animasyon ve simülasyonu kullandıklarına ve neden bu aşamada animasyon ve simülasyonu seçtiklerine yönelik görüşleri incelenmiş ve elde edilen bulgular Şekil 3'te sunulmuştur.

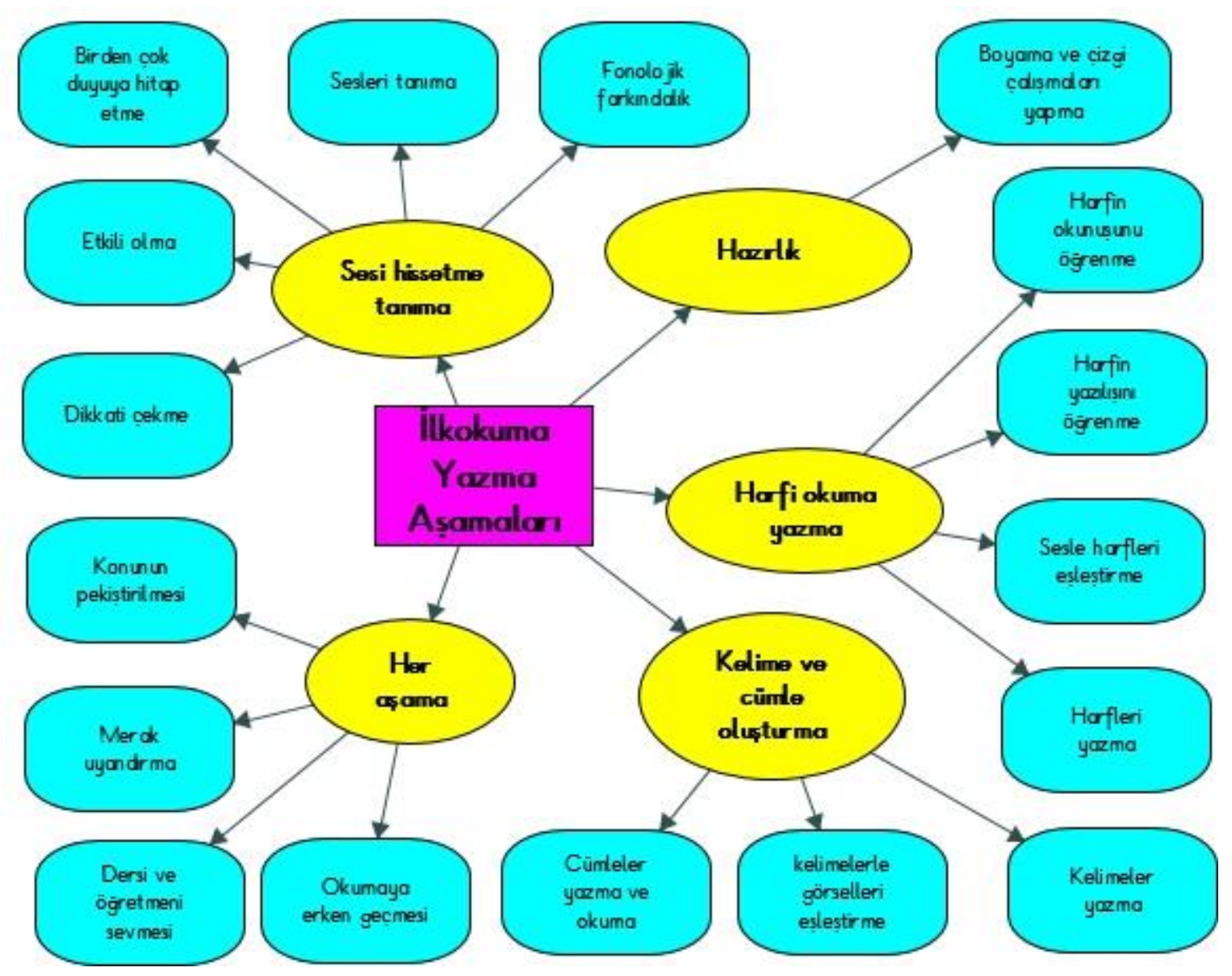

Şekil 3. Öğretmeni Adaylarının Ses Esaslı Illkokuma Yazma Öğretim Sürecinin Hangi Aşamasında Animasyon ve Simülasyonu Kullandıklarına ve Neden Bu Aşamada Animasyon ve Simülasyonu Seçtiklerine Yönelik Görüşleri

Şekil 3 incelendiğinde öğretmen adayları, ses esaslı ilkokuma yazma öğretimi sürecinin sesi hissetme ve tanıma, hazırlık, harfi okuma-yazma ilee kelime ve cümle oluşturma aşamalarında animasyon ve simülasyonu kullandıklarını belirtmişlerdir. Öğretmen adayları tarafından daha çok sesi hissetme ve tanıma aşamasında animasyon ve simülasyon kullandıkları belirtilmiştir. Ayrıca bazı öğretmen adayları tarafından ses esaslı ilkokuma yazma öğretim sürecinin her aşamasında animasyon 
ve simülasyon kullandıkları da belirtilmiştir. Öğretmen adayları hazırlık aşamasında, boyama ve çizgi çalışmalarını kolayca yapmalarından dolayı; sesi hissetme ve tanıma aşamasında öğrencilerin dikkati çekmesinden, öğrencilerin harfleri yazmasında etkili olmasından, birden çok duyuya hitap etmesinden, sesleri tanımalarını sağlamasından ve fonolojik farkındalığı geliştirmesinden dolayı animasyon ve simülasyon kullandıklarını belirtmişlerdir. Bir öğretmen adayının görüşü şu şekildedir:

"Ben animasyon ve simülasyonu sesi hissetme ve tanıma aşamasında kullandım. Çünkü yeni bir sesi öğretirken ne kadar duyu organına hitap edersek öğrenciler sesi o kadar kolay tanırlar ve öğrenirler. Bu sebeple bahsettiğim aşamada kullandım." (ÖA:3, K)

Öğretmen adayları ses esaslı ilkokuma yazmanın harfi okuma-yazma aşamasında harfin yazılışını ve okunuşunu öğrenmesine katkı sağlamasından, seslerle harfleri eşleştirmelerine yardımcı olmasından, harfleri yazmalarına yardımcı olduğundan; kelimeler ve cümleler oluşturma aşamasında kelimeleri yazmalarını, kelimelerle görselleri eşleştirmelerini, cümleleri okuyup yazmalarını sağladığından dolayı animasyon ve simülasyon kullandıklarını belirtmişlerdir. Öğretmen adayları ses esaslı okuma yazma öğretiminin her aşaması temasında ise öğrencilerin okumaya erken geçmelerini sağladığından, dersi ve öğretmeni sevdirdiğinden, merak uyandırdığından, konunun pekiştirilmesini sağladığından dolayı animasyon ve simülasyonu kullandıklarını belirtmişlerdir. Bazı öğretmen adaylarına ait görüşlere aşağıda yer verilmiştir.

"Harfin okuma-yazma aşamasında kullandım. Harfin okunması ve yazılması ilkokuma yazmanın en önemli aşamasıdır. Animasyonlar sayesinde harfin nasıl okunması gerektiğini öğrenirken, simülasyonlar sayesinde de öğrenciler harfin nasıl yazılması gerektiğini yazarak öğrendiler." (ÖA:10, E)

Araştırmanın dördüncü alt problemine dayalı olarak, sınıf öğretmeni adaylarının ilkokuma yazma öğretiminde animasyon ve simülasyon kullanımı esnasında yaşadıkları sorunlara ilişkin görüşleri incelenmiş ve elde edilen bulgular Şekil 4'te sunulmuştur.

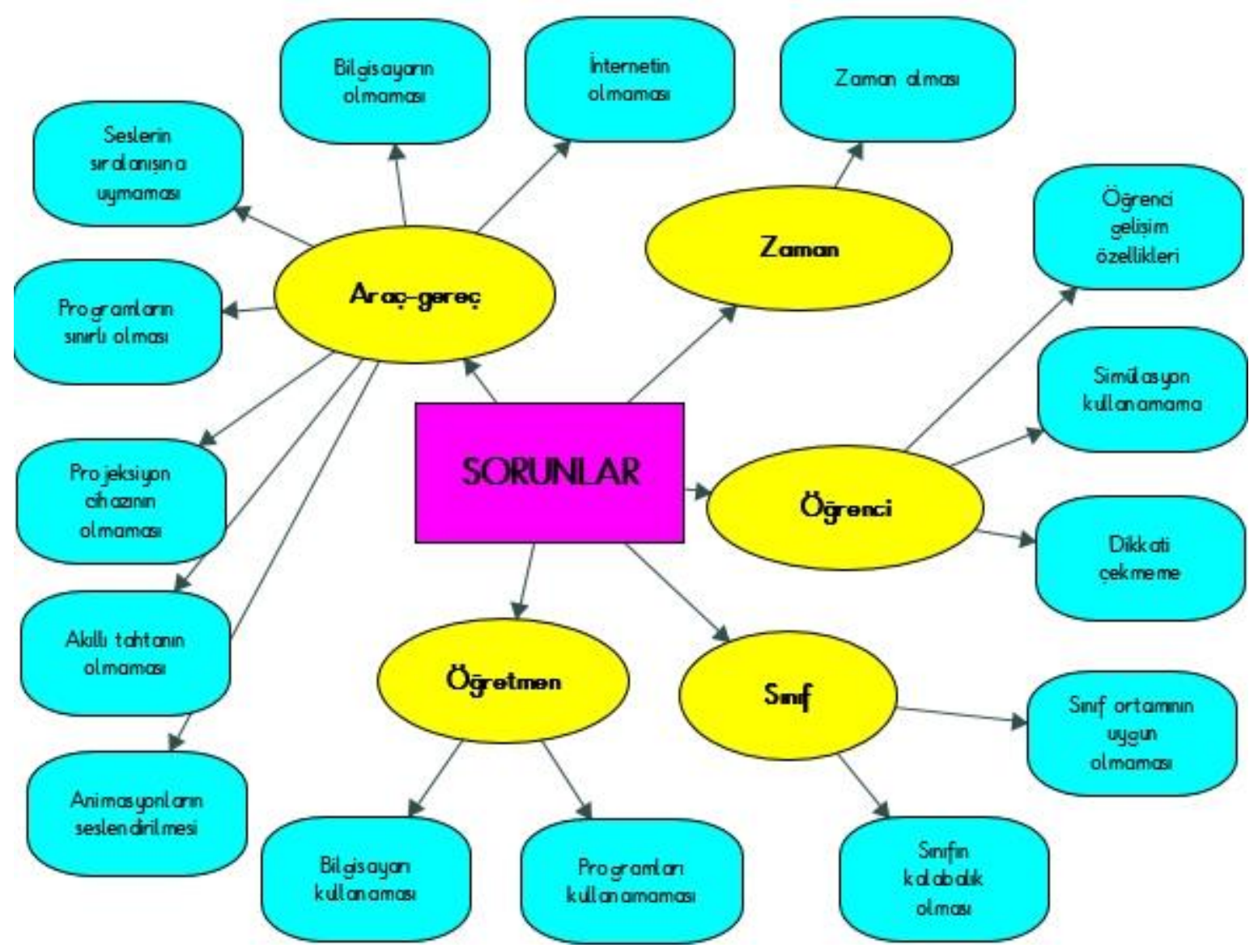

Şekil 4. Öğretmeni Adaylarının İlkokuma Yazma Öğretiminde Animasyon ve Simülasyon Kullanımı Esnasında Yaşadıkları Sorunlara İlişkin Görüşleri 
Şekil 4 incelendiğinde öğretmen adayları, animasyon ve simülasyon kullanımı ile ilgili olarak araç-gereç, öğrenci, sınıf, öğretmen ve zaman temalarında sorunlar yaşadıklarını belirtmişlerdir. Öğretmen adayları tarafından, ilkokuma yazma öğretiminde animasyon ve simülasyon kullanırken daha çok araç-gereç temasında sorun yaşadıkları ifade edilmiştir. Öğretmen adayları araç-gereç temasında internetin olmaması, bilgisayarın olmaması, seslerin sıralanışına uymaması, animasyon ve simülasyon programlarının sınırlarının olması, projeksiyon cihazının olmaması, akıllı tahtanın olmaması, animasyonların seslendirilmesinde sorun yaşadıklarını belirtmişlerdir. Bir öğretmen adayının görüşü şu şekildedir:

"Benim öğretmenlik uygulaması için gittiğim okulda internet problemini çok yaşadım. Internet çok gidip geldi. Bu nedenle animasyon ve simülasyonları uygularken çok sorun yaşadım." (ÖA:17,K)

Öğretmen adayları öğrenci temasında öğrenci gelişim özelliklerine uygun animasyon hazırlanamaması, öğrencilerin simülasyonu kullanamaması, dikkatini çekmemesi gibi sorunlarla karşılaştıklarını belirtmişlerdir. Bir öğretmen adayının görüşü şu şekildedir:

"Hocam maalesef derste kullandığım simülasyonlardan bazılarını ögrenciler yapamadı. Daha önce hiç görmemişler. Nasıl kullanılacağını bilmiyolardı. Bu nedenle sorun yaşadım." (ÖA:15, K)

Öğretmen adayları öğretmen temasında öğretmenin bilgisayarı kullanamaması, animasyon ve simülasyon programlarını kullanamamasından dolayı sorun yaşadıklarını belirtmişlerdir. Öğretmen adayı 21'in görüşü şu şekildedir:

"Ben animasyon programını kullanırken zorluk çektim. Bu konuda keşke derste hocamı daha iyi dinleseydim dedim." (ÖA:21, K)

Öğretmen adayları sınıf temasında sınıf ortamının uygun olmaması, sınıfın kalabalık olması; zaman temasında animasyon ve simülasyon hazırlamanın zaman almasından dolayı sorunlarla karşılaştıklarını belirtmişlerdir. Bazı öğretmen adaylarına ait görüşlere aşağıda yer verilmiştir.

"Staj yaptığım sınıf çok kalabalıktı. Öğrenci sayısı 36'ydı. Bu nedenle animasyon ve simülasyonları çok iyi uygulayamadım." (ÖA:24, E)

Araştırmanın beşinci alt problemine dayalı olarak, sınıf öğretmeni adaylarının ilkokuma yazma öğretiminde animasyon ve simülasyon kullanımı esnasında yaşadıkları sorunlara yönelik geliştirmiş oldukları çözüm önerilerine ilişkin görüşleri incelenmiş ve elde edilen bulgular Şekil 5'te sunulmuştur.

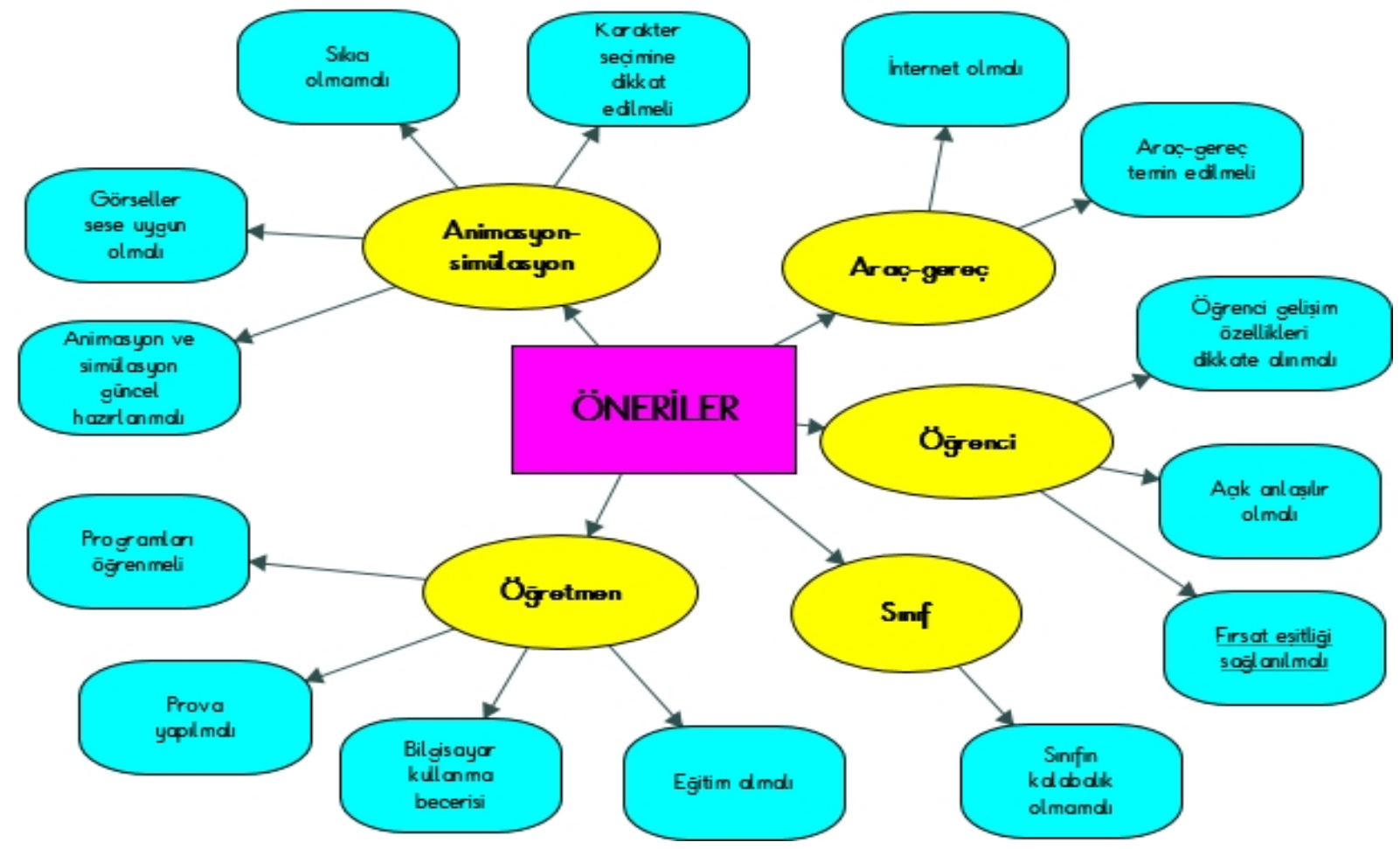

Şekil 5. Öğretmeni Adaylarının İlkokuma Yazma Öğretiminde Animasyon ve Simülasyon Kullanımı Esnasında Yaşadıkları Sorunlara Yönelik Geliştirmiş Oldukları Çözüm Önerilerine iliş̧kin Görüşleri 
Şekil 5 incelendiğinde öğretmen adayları, animasyon ve simülasyon kullanımına yönelik yaşamış oldukları sorunlara ilişkin araç-gereç, öğrenci, sınıf, öğretmen, animasyon ve simülasyon temalarında öneriler geliştirmişlerdir. Öğretmen adayları, ilkokuma yazma öğretiminde animasyon ve simülasyon kullanırken karşılaşmış oldukları sorunlara yönelik daha çok araç-gereç teması ile ilgili öneriler geliştirmişlerdir. Öğretmen adayları araç-gereç temasında internet olmalı, araç-gereçler temin edilmeli önerilerini geliştirmişlerdir. Bir öğretmen adayı şu şekilde görüş ifade etmiştir:

"Animasyon ve simülasyonların etkili bir şekilde kullanılabilmesi için kesinlikle okullarda internet olmalı ve bunun için okul müdürü gerekli çalışmaları yapmalıdır." (ÖA:8, K)

Öğretmen adayları öğrenci temasında öğrenci gelişim özellikleri dikkate alınmalı, animasyonlar açık anlaşılır olmalı, fırsat eşitliği sağlanılmalı önerilerini geliştirmişlerdir. Öğretmen adayı 21 'in görüşü şu şekildedir:

"Bence hazırlanacak animasyonlar öğrencilerin anlayacağı bir şekilde, açık, anlaşılır hazırlanmalı. Öğrenciler daha iyi anlarlar." (ÖA:21, K)

Öğretmen adayları öğretmen temasında öğretmen animasyon ve simülasyon programlarını öğrenmeli, prova yapmalı, bilgisayar kullanma becerisini geliştirmeli, animasyon ve simülasyon hazırlama ile ilgili eğitim almalı; sınıf temasında sınıf kalabalık olmamalı; animasyon ve simülasyon temasında animasyonlarda karakter seçimine dikkat edilmeli, animasyonlar sıkıcı olmamalı, animasyon ve simülasyonlarda görseller öğrencilerin gelişim özelliklerine uygun olmalı ve animasyon-simülasyon güncel hazırlanmalı önerilerini geliştirmişlerdir. Bazı öğretmen adaylarına ait görüşlere aşağıda yer verilmiştir.

"Öğretmen kullanacağı programı çok iyi tanımalıdır. Çok iyi öğrenmelidir. Aksi takdirde çok iyi animasyon veya simülasyon hazırlayamaz, uygulayamaz." (ÖA:19, K)

\section{Tartışma, Sonuç ve Öneriler}

Bu araştırmanın amacı, sınıf öğretmeni adaylarının ilkokuma yazma öğretiminde animasyon ve simülasyon kullanımına yönelik deneyimleri ile ilgili görüşlerini incelemektir. Türkiye'de alanyazın incelendiğinde böyle bir çalışmaya rastlanılmamıştır. Bu açından yapılan bu araştırmanın öncü niteliğinde bir araştırma olduğu ifade edilebilir. Araştırma sonuçlarının ilkokuma yazma öğretiminde animasyon ve simülasyon ile ilgili araştırma yapacaklara ışık tutacağı umulmaktadır. Araştırmanın ilk alt problemine dayalı olarak sınıf öğretmeni adaylarının animasyon ve simülasyon ile ilgili görüşleri incelenmiştir. Öğretmen adayları animasyon ve simülasyon ile ilgili olarak kullanımlarının kolay olduğunu, eğitimde kullanılmasının önemli olduğunu, öğrenmeyi kolaylaştırdığını, kalıcı öğrenmeyi sağladığını, öğrencilerin okuma yazmaya geçmesini kolaylaştırdığını, somutlaştırmayı sağladığını, eğlenceli olduğunu, öğrencilerin dersi sevmelerini sağladığını, birden çok duyuya hitap ettiğini, keşfederek öğrenmeyi sağladığını, öğretme-öğrenme sürecine teknoloji entegrasyonunu sağladığını, öğretmenin mesleki gelişimine katkı sağladığını, yapılandırmacı yaklaşıma uygun olduğunu, öğrenciyi öğretme-öğrenme sürecinde aktif kıldığını, öğrencilere uygulama yapma imkanı verdiğini ve öğrencilerin tekrar izlemesini sağladığını belirtmişlerdir. Araştırmanın bu sonucuna dayalı olarak, öğretmen adaylarının animasyon ve simülasyon ile ilgili bilgi sahibi oldukları ve eğitimde animasyona ve simülasyon kullanımına yönelik olumlu görüşlere sahip oldukları söylenebilir. Bu durum araştırmacı tarafından olumlu olarak değerlendirilmektedir. Çünkü öğretmen adaylarının animasyon ve simülasyon gibi teknolojik araçlara yönelik olumlu görüşlerinin olması, göreve başladıklarında bu araçları kullanacaklarını düşündürmektedir. Bunun neticesinde de, 21. yüzyıl becerilerine sahip öğrencilerin yetiştirilebileceği söylenilebilir. Birgül (2014) tarafından yapılan araştırmada, sınıf öğretmenleri ilkokuma yazma öğretiminde bilgisayar destekli öğretime yönelik olumlu görüşlere sahip oldukları sonuçları elde edilmiştir. Bu çalışmaya dayalı olarak, hem öğretmenlerin hem de öğretmen adaylarının ilkokuma yazma öğretiminde teknoloji entegrasyonuna olumlu baktıkları ifade edilebilir.

Araştırmada öğretmen adaylarının, ilkokuma yazma öğretiminde animasyon ve simülasyon kullanımının katkısına yönelik görüşleri de incelenmiştir. Araştırma sonucunda öğretmen adayları tarafından, öğretme-öğrenme ortamında animasyon ve simülasyon kullanımının en çok öğrenciye katkı sağladığı belirtilmiştir. Öğretmen adayları öğrenci temasında, kalıcı öğrenmeyi sağladığını, somutlaştırmayı sağladığını, öğrenmeyi kolaylaştırdığını, öğrencilerin dikkatini çektiğini, ilgisini 
arttırdığını, akıcı okumalarını sağladığını, istekli olmalarını sağladığını, öğrendiklerini pekiştirmelerine yardımcı olduğunu, akademik başarılarını ve motivasyonunu arttırdığını, özgüvenlerini sağladığını, derse uyum sağlamalarına yardımcı olduğunu, derinlemesine öğrenmelerini sağladığını; öğretmeöğrenme süreci temasında, öğrenme-öğretme sürecinin eğlenceli olmasını sağladığını, bu süreçte öğrenciyi aktif kıldığını, etkili öğretimin gerçekleşmesine yardımcı olduğunu; öğretmen teması altında, öğretmenlere harflerin öğretilmesinde yardımcı olduğunu, öğretmenlerin dersi iyi planlamalarına katkı sağladığını, zamandan tasarruf sağladıklarını, dijital teknolojiyi kullanma becerilerini geliştirdiğini, mesleki gelişimlerine katkı sağladıklarını, yükünü azalttıklarıı; sınıf yönetimi temasında disiplin sorunlarını azalttığını belirtmişlerdir. Araştırmanın bu sonucu oldukça önemlidir. Araştırma sonucuna göre, öğretmen adayları ilkokuma yazma öğretiminde animasyon ve simülasyon kullanımının oldukça faydalı olduğunu belirtmişlerdir. Animasyonun birden fazla duyuya hitap etmesi, dinamik süreçleri görselleştirmesi, etkileşimli ortamlar sunması, öğrenme sürecini eğlenceli hale getirmesi, öğrenmede kalıcılığı arttırması, motivasyonu arttırması (Mayer, 2005; Telli, 2019; Xiao, 2013), simülasyonların ise motivasyonu arttırma, zamandan tasarruf sağlama, keşfedici öğrenmeyi sağlama, öğrenmeyi kalıcı hale getirme, öğrencilerin süreçte aktif olmalarını sağlama, tekrar imkanı vermesi (Sarıçayır, 2007; Telli, 2019; West \& Graham, 2005) gibi yararları bulunmaktadır. Bu bakımdan öğretmen adaylarının ilkokuma ve yazma öğretiminde animasyon ve simülasyon kullanımı ile ilgili belirtmiş olduğu görüşler alanyazınla örtüşmektedir. İğdirsel (2012) tarafından yapılan araştırma sonucunda, sınıf öğretmenleri ilkokuma yazma öğretiminde CD'lerin kullanımının öğrencilerin öğrenmelerini kolaylaştırdığını ve öğrenme-öğretme ortamını eğlenceli hale getirdiğini belirtmişlerdir. Bu sonuç yapılan bu araştırma sonucunu destekler niteliktedir.

Araştırma kapsamında öğretmen adaylarının ses esaslı ilkokuma yazma öğretimi sürecinin hangi aşamasında animasyon ve simülasyon kullandıkları ve neden bu aşamada animasyon ve simülasyonu tercih ettikleri de incelenmiştir. Öğretmen adayları, ses esaslı ilkokuma yazma öğretimi sürecinin sesi hissetme ve tanıma, hazırlık, harfi okuma yazma ve kelime ve cümle oluşturma aşamalarında animasyon ve simülasyonu kullandıklarını belirtmişlerdir. Öğretmen adayları tarafından daha çok sesi hissetme ve tanıma aşamasında animasyon ve simülasyon kullandıkları belirtilmiştir. Ayrıca bazı öğretmen adayları tarafından ses esaslı ilkokuma yazma öğretim sürecinin her aşamasında animasyon ve simülasyon kullandıkları da belirtilmiştir. Öğretmen adayları hazırlık aşamasında, boyama ve çizgi çalışmalarını kolayca yapmalarından dolayı; sesi hissetme ve tanıma aşamasında öğrencilerin dikkati çekmesinden, öğrencilerin harfleri yazmasında etkili olmasından, birden çok duyuya hitap etmesinden, sesleri tanımalarını sağlamasından ve fonolojik farkındalığı geliştirmesinden; harfi okuma-yazma aşamasında harfin yazıışını ve okunuşunu öğrenmesine katkı sağlamasından, seslerle harfleri eşleştirmelerine yardımcı olmasından, harfleri yazmalarına yardımcı olduğundan; kelimeler ve cümleler oluşturma aşamasında kelimeleri yazmalarını, kelimelerle görselleri eşleştirmelerini, cümleleri okuyup yazmalarını sağladığından dolayı animasyon ve simülasyon kullandıklarını belirtmişlerdir. Öğretmen adayları her aşama temasında ise öğrencilerin okumaya erken geçmelerini sağladığından, dersi ve öğretmeni sevdirdiğinden, merak uyandırdığından, konunun pekiştirilmesini sağladığından dolayı animasyon ve simülasyonu kullandıklarını belirtmişlerdir. Aladağ (2012) tarafından yapılan araştırmada, sınıf öğretmenleri bilgisayar destekli öğretimin ses temelli cümle yönteminin her aşamasında kullandıklarını belirtmişlerdir. Danacı (2019) ve Ceylan (2018) tarafından yapılan araştırmalarda, animasyon destekli öğretimin öğrencilerin akademik başarılarını arttırdığı sonucu elde edilmiştir. Bu araştırmaların sonuçları yapılan bu araştırmanın sonucu ile örtüşmektedir.

Araştırmada sınıf öğretmeni adaylarının ilkokuma yazma öğretiminde animasyon ve simülasyon kullanırken karşılaşmış oldukları sorunlar da incelenmiştir. Araştırma neticesinde öğretmen adayları, animasyon ve simülasyon kullanımı ile ilgili olarak araç-gereç, öğrenci, sınıf, öğretmen ve zaman temalarında sorunlar yaşadıklarını belirtmişlerdir. Öğretmen adayları tarafından ilkokuma yazma öğretiminde animasyon ve simülasyon kullanırken daha çok araç-gereç temasında sorun yaşadıkları belirtilmiştir. Öğretmen adayları araç-gereç temasında internetin olmaması, bilgisayarın olmaması, seslerin sıralanışına uymaması, animasyon ve simülasyon programlarının sınırlarının olması, projeksiyon cihazının olmaması, akıllı tahtanın olmaması, animasyonların seslendirilmesinde; öğrenci 
temasında öğrenci gelişim özelliklerine uygun animasyon hazırlanamaması, öğrencilerin simülasyonu kullanamaması, dikkatini çekmemesi; öğretmen temasında öğretmenin bilgisayarı kullanamaması, animasyon ve simülasyon programlarını kullanamaması; sınıf temasında sınıf ortamının uygun olmaması, sınıfın kalabalık olması; zaman temasında animasyon ve simülasyon hazırlamanın zaman almasından dolayı sorunlarla karşılaştıklarını belirtmişlerdir. Aladağ (2012) tarafından yapılan araştırmada, sınıf öğretmenleri bilgisayar destekli öğretimin ilkokuma yazma öğretiminde benzer sorunlarla karşılaştıklarını belirtmişlerdir. Bilgisayar destekli eğitimde araç gereçlerden dolayı sorunlar yaşanması, eğitimcilerin bilgisayar kullanma becerilerinin iyi olmaması bu eğitimin bir sınırlılığ olarak belirtilmektedir (Bayram, 2019; Ceylan, 2018).

Araştırmada son olarak öğretmen adaylarının ilkokuma yazma öğretiminde animasyon ve simülasyon kullanırken karşılaşmış oldukları sorunlara yönelik çözüm önerileri incelenmiştir. Öğretmen adayları, animasyon ve simülasyon kullanımına yönelik yaşamış oldukları sorunlara ilişkin araç-gereç, öğrenci, sınıf, öğretmen, animasyon ve simülasyon temalarında öneriler geliştirmişlerdir. Bunun sebebi ise öğretmen adayların animasyon ve simülasyon kullanırken daha çok araç gereçlerden dolayı sorun yaşamalarıdır. Bu nedenle öğretmen adaylarının daha çok bu tema altında öneri geliştirdikleri söylenebilir. Öğretmen adayları, ilkokuma yazma öğretiminde animasyon ve simülasyon kullanırken karşılaşmış oldukları sorunlara yönelik daha çok araç-gereç teması ile ilgili öneriler geliştirmişlerdir. Öğretmen adayları araç-gereç temasında internet olmalı, araç-gereçler temin edilmeli; öğrenci temasında öğrenci gelişim özellikleri dikkate alınmalı, animasyonlar açık anlaşılır olmalı, fırsat eşitliği sağlanmalı; öğretmen temasında öğretmen animasyon ve simülasyon programlarını öğrenmeli, prova yapmalı, bilgisayar kullanma becerisini geliştirmeli, animasyon ve simülasyona hazırlama ile ilgili eğitim almalı; sınıf temasında sınıf kalabalık olmamalı; animasyon ve simülasyon temasında animasyonlarda karakter seçimine dikkat edilmeli, animasyonlar sıkıcı olmamalı, animasyon ve simülasyonlarda görseller öğrencilerin gelişim özelliklerine uygun olmalı ve animasyon-simülasyonlar güncel hazırlanmalı önerileri geliştirilmiştir.

Araştırma sonuçlarına dayalı olarak şu önerilerde bulunulabilir:

1. Sınıf öğretmeni adayları ilkokuma yazma öğretiminde animasyon ve simülasyon kullanımının birçok faydasının olduğunu belirtmişlerdir. Bu sonuca dayalı olarak, ilkokuma yazma öğretiminde animasyon ve simülasyon kullanımının özellikle öğrencilere önemli katkıları olacaktır. Öğretmenlere ilkokuma yazma öğretiminde animasyon simülasyon kullanmaları önerilmektedir.

2. Öğretmen adayları ilkokuma yazma öğretiminde animasyon ve simülasyon kullanımı ile ilgili özellikle araç-gereçlerden kaynaklı sorunlar yaşadıklarını belirtmişlerdir. Öğretmen adayları tarafından belirtilen araç gereçler ile ilgili sorunlar Milli Eğitim Bakanlığı tarafından giderilmelidir. Milli Eğitim Bakanlığı tarafından okullara gerekli araç gereç temin edilmelidir. Okulların alt yapıları güçlendirilmelidir. Bunun sonucunda öğretmenler tarafından nitelikli bir şekilde teknoloji entegrasyonu sağlanabilir ve 21 . yüzyıl becerileri ile donatılmış bireyler yetiştirilebilir.

3. Illkokuma yazma öğretiminde animasyon ve simülasyon kullanımının öğrencilerin okuma ve yazma becerilerine etkisini araştıran deneysel, durum çalışması, eylem araştırması gibi araştırma modeli ve desenlerinin kullanıldığı araştırmaların yapılması alanyazına katkı sağlayacaktır.

\section{Kaynaklar}

Aladağ, U. (2012). ilkokuma yazma öğretiminde, bilgisayar destekli öğretim yöntemine ilişkin öğretmen görüşlerinin incelenmesi (Ağrı ili örneği). Yayımlanmamış yüksek lisans tezi. Erzincan Üniversitesi, Erzincan.

Arıcı, E. \& Dalkılıç, E. (2006). Animasyonların bilgisayar destekli öğretime katkısı: bir uygulama örneği. Kastamonu Ĕgitim Dergisi, 14(2), 421-430.

Bayram, Y. (2019). Simülasyon (benzetim) destekli 5e öğrenme döngüsü modelinin 7. sınıföğrencilerinin elektrik konusunu anlamalarına ve elektrik konusuna yönelik ilgilerine etkisinin incelenmesi. Yayımlanmamış yüksek lisans tezi. Bartın Üniversitesi, Bartın.

Beşkirli, M. (2011). Eğitimde bilgisayar destekli animasyon tasarımı ve gerçekleştirilmesi. Yayınlanmamış yüksek lisans tezi. Bilecik Üniversitesi, Bilecik. 
Birgül, K. (2014). Sınıf öğretmenlerinin bilgisayar destekli ilkokuma yazma öğretimine ilişkin görüş ve tutumlarının belirlenmesine yönelik bir araştırma. Yayımlanmamış yüksek lisans tezi. Uludağ Üniversitesi, Bursa.

Ceylan, N. (2018). Bilgisayar animasyonları destekli 5e öğrenme modelinin "tepkimelerde hız ve denge" konusunda akademik başarı üzerine etkisi. Yayımlanmamış doktora tezi. Hacettepe Üniversitesi, Ankara.

Chong, A., Sourin A., \& Levinski, K. (2006). Grid-based computer animation rendering. in proceedings of the 4th international conference on computer graphics and interactive techniques in Australasia and Southeast Asia, pp. 39-47.

Cresswell, J.W. (2007). Qualitative inquiry \& research design choosing amang five appproaches. London: SAGE.

Danacı, F. (2018). Maddenin tanecikli yapısının animasyonla öğretiminin öğrencilerin akademik başarıları üzerindeki etkisi. Yayımlanmamış yüksek lisans tezi. Van Yüzüncü Yı Üniversitesi, Van.

Funge, J. D. (1998). Making them behave cognitive models for computer animation. Ph.D. Thesis, University of Toronto, Graduate Department of Computer Science, Toronto, Canada.

Güçlü, İ. (2019). Sosyal bilimlerde nitel araştırma yöntemleri. Ankara: Nobel Yayıncılık.

Güler, A., Halıcıoğlu, M.B. \& Taşğın, S. (2014). Sosyal bilimlerde nitel araştırma yöntemleri. Ankara: Seçkin Yayıncılık.

Günüç, S. (2017). Eğitimde teknoloji entegrasyonun kuramsal temelleri. Ankara: Anı Yayıncılık.

Gürbüz, S. \& Şahin, F. (2018). Sosyal bilimlerde araştırma yöntemleri: Felsefe-yöntem-analiz. Ankara: Seçkin Yayıncılık.

Hammersley, M. \& Traianou, A. (2012). Ethics in qualitative research: controversies and contexts. London: SAGE Pub.

İğdirsel, T. (2012). Illköğretim birinci sınıf öğretmenlerinin görüşlerine göre ilkokuma-yazma cd’ lerinin değerlendirilmesi. Yayımlanmamış yüksek lisans tezi. Uşak Üniversitesi, Uşak.

Karaçöp, A. (2010). Öğrencilerin elektrokimya ve kimyasal bağlar ünitelerindeki konuları anlamalarına animasyon ve jigsaw tekniklerinin etkileri. Yayınlanmamış doktora tezi. Atatürk Üniversitesi, Erzurum.

Karagöz, Y. (2018). SPSS ve AMOS uygulamalı: Nitel-nicel-karma bilimsel araştırma yöntemleri ve yayın etiği. Ankara: Nobel Yayıncılık.

Klassen, K.J. \& Willoughby, K.A. (2003). In-Class simulation games: assessing student learning. Journal of Information Technology Education, 2, 1-13.

Mayer, R.E. (2005). Cognitive theory of multimedia learning. In R.E. Mayer (Edt.) Cambridge handbook of multimedia leraning. New York: Cambridge University Press.

MEB. (2019). Türkçe dersi öğretim programı (ilkokul ve ortaokul1, 2, 3, 4, 5, 6, 7 ve 8. sınıflar). Ankara: Devlet Kitap Basımevi.

Patton, M.Q. (2005). Qualitative resarch. New York: John Wiley \& Sons.

Sarıçayır, H. (2007). Kimya eğitiminde kimyasal tepkimelerde denge konusunun bilgisayar destekli ve laboratuar temelli öğretiminin öğrencilerin kimya başarılarına, hatırlama düzeylerine ve tutumlarına etkisi. Yayınlanmamış yüksek lisans tezi. Marmara Üniversitesi, İstanbul.

Shubik, M. (2009). It is not just a game! Simulation \& Gaming, 40(5), 587-601.

Sığrı, Ü. (2019). Nitel araştırma yöntemleri. İstanbul: Beta Yayınları.

Sönmez, V. \& Alacapınar, F.G. (2018). Örneklendirilmiş bilimsel araştırma yöntemleri. Ankara: Anı Yayıncılık.

Telli, E. (2019). Eğitimde animasyon, simülasyon ve video kullanımı. Y.K. Türel (Edt.) Öğretim teknolojileri. Ankara: ASOS Yayınları.

West, R.E. \& Graham, C.R. (2005). Five powerful ways technology can enhance teaching and learning in higher education. Educational Technology, 45(3), 20-27.

Xiao, L. (2013). Animation trends in education. International Journal of Information and Education Technology, 3(3), 286.

Yıldırım, A., \& Şimşek, H. (2018). Sosyal bilimlerde nitel araştırma yöntemleri. Ankara: Seçkin Yayıncılık. 
Yıldız, S. (2009). Illkokuma yazma öğretiminde çoklu ortam uygulamalarının etkililiği. Yayınlamamış doktora tezi. Abant İzzet Baysal Üniversitesi, Bolu.

Zapalska, A., Brozik, D. \& Rudd, D. (2012). Development of active learning with simulations and games. US-China Education: David Publishing.

\section{Extended Abstract}

Introduction

It is of most importance that the elementary school first grade students gain the quality of reading and writing, which are the most important skills that will affect their lives. For this reason, technology integration should be done in teaching first reading and writing. It has been mentioned above that education based on technology integration has many contributions to students. In this regard, teachers should have knowledge about technology integration and use the latest technology in the teaching-learning environment. Two of them are animation and simulation applications. As mentioned above, animation and simulation applications have many contributions to students. In order for teachers to use animation in first reading and writing education, they should have knowledge and experience in their pre-service training on this subject. In this research, animations and simulations were prepared for prospective teachers in the first reading and writing lessons given by the researcher, and activities related to first reading and writing were applied to the students within the framework of these animations and simulations. Based on the experience of prospective teachers, the study of the experience of using animation and simulation in teaching first reading and writing has been considered as a research subject. The absence of any study on this subject in the literature was seen as a shortcoming and it was thought that this study would fill this gap in the literature. The aim of this research is to examine the experiences of elementary prospective teachers on the use of animation and simulation in teaching first reading and writing.

\section{Method}

Qualitative research model was used in the research. Participants of the research are Süleyman Demirel University, prospective teachers studying in the fourth grade of primary school teaching. Criterion sampling method was used while determining the participants of the research. The participants of the researcher are 13 female and 11 male candidate teachers. In the research, a questionnaire form was used as a data collection tool. The questionnaire enables the participants to obtain their thoughts, attitudes and behaviors on a subject based on the questions created in a previously determined order and structure. In this study, a questionnaire developed to examine the experiences of elementary prospective teachers on the use of animation and simulation in teaching first reading and writing was used. The questions in the questionnaire form consist of open-ended questions. The questionnaire prepared was applied to prospective teachers between 9-13/12/2019. A questionnaire was applied to prospective teachers who participated in the study voluntarily by the researcher. Questionnaire forms were filled in their spare time in a way not to disrupt the prospective teachers' education. Prospective teachers answered open-ended questions in the questionnaire on average 35 minutes. Content analysis, one of the qualitative data analysis, was used in the analysis of the data. Within the scope of the research, the answers given by the preservice teachers to the questionnaire form were examined one by one and then the codes were reached, and then these codes were associated with each other and themes were created. The data were analyzed using the Nvivo 11 program and the findings obtained are presented in the figures. Various strategies are used in qualitative research to ensure validity and reliability. Various strategies such as obtaining expert opinion, confirmation of participants, and agreement between codings have been employed in ensuring validity and reliability in the research.

\section{Result and Discussion}

Prospective teachers are easy to use in terms of animation and simulation, it is important to use in education, facilitate learning, provide permanent learning, make students easy to read and write, embody, make fun, make students love the lesson, appeal to multiple senses, provide learning 
by exploring. It has been determined that it provides technology integration into the teaching-learning process, contributes to the professional development of the teacher, is suitable for the constructivist approach, activates the student in the teaching-learning process, gives students the opportunity to practice and allows students to watch again. Based on this result of the research, it can be said that prospective teachers have knowledge about animation and simulation and have positive views on animation and simulation use in education.

As a result of the research, it was stated by the prospective teachers that the use of animation and simulation in the teaching-learning environment contributes the most to the students. According to the results of the research, the use of animation and simulation is very useful in teaching first reading and writing. Animation appeals to multiple senses, visualizes dynamic processes, offers interactive environments, makes learning process fun, increases permanence in learning, increases motivation (Mayer, 2005; Telli, 2019; Xiao, 2013), simulations increase motivation, save time, There are benefits such as providing exploratory learning, making learning permanent, enabling students to be active in the process, giving it the opportunity to repeat (Sarıçayır, 2007; Telli, 2019; West \& Graham, 2005). As a result of the research by İgdirsel (2012), elemantary teachers stated that the use of CDs in first reading and writing instruction facilitates students' learning and makes the learningteaching environment enjoyable.

Prospective teachers stated that they used animation and simulation in the stages of sound based first reading and writing teaching process in feeling and recognizing, preparing, reading, writing, and creating words and sentences. As a result of the research, prospective teachers stated that they had problems in the theme of equipment, student, classroom, teacher and time related to the use of animation and simulation. In the study carried out by Aladağ (2012), elemantary teachersstated that computer aided education faced similar problems in teaching first reading and writing. It is stated that there are problems in computer-aided education due to equipment and the computer skills of the educators are not good as a limitation of this education (Bayram, 2019; Ceylan, 2018). Prospective teachers have developed suggestions on the themes of equipment, students, class, teachers, animation and simulation related to the problems they have experienced with the use of animation and simulation. Prospective teachers have developed suggestions on the theme of tools and equipment for the problems they encounter while using animation and simulation in teaching first reading and writing. 